\title{
Paliperidone Palmitate for Schizophrenia
}

\author{
Abraham M. Nussbaum* ${ }^{* 1,2}$ and T. Scott Stroup ${ }^{3}$ \\ ${ }^{1}$ Behavioral Health, Denver Health, Denver, CO; ${ }^{2}$ Psychiatry, University of Colorado, Aurora, CO; ${ }^{3}$ Psychiatry, Columbia University, \\ New York, NY \\ *To whom correspondence should be addressed; Behavioral Health Service, Denver Health, MC 0490, 777 Bannock Street, Denver CO \\ 80204, US; tel: 303-602-6920, fax: 303-602-6930, e-mail: abraham.nussbaum@dhha.org
}

Key words: schizophrenia/paliperidone palmitate/ systematic review/meta-analysis

\section{Background}

Paliperidone palmitate, a long-acting intramuscular formulation of paliperidone, is now available for clinical use. Paliperidone is an active metabolite of risperidone, and it is also available in an oral formulation for daily use.

\section{Objectives}

To compare effects of paliperidone palmitate with any other treatment for people with schizophrenia and schizophrenia-like illnesses. ${ }^{1}$

\section{Search Methods}

We searched the Cochrane Schizophrenia Group's Register (November 2009) and inspected references of identified studies for further trials. We contacted the manufacturers of paliperidone palmitate, the Food and Drug Administration, and authors of relevant trials for additional material.

\section{Selection Criteria}

We included all relevant randomized controlled trials (RCTs).

\section{Data Collection and Analysis}

We independently selected and critically appraised studies, extracted data and analyzed on an intention-to-treat basis. Where possible and appropriate, we calculated risk ratios (RRs) and their 95\% confidence intervals (CIs) with the number needed to benefit/harm statistic $(\mathrm{NNB} / \mathrm{H})$. We calculated weighted mean differences (MD) for continuous data.

\section{Results}

Five studies with 2215 participants compared paliperidone palmitate with placebo. Fewer people left studies early if they were randomized to paliperidone palmitate $(n=2183,5$ RCTs, RR 0.76 CI $0.70-0.84$, NNTB 9 CI 7-14) and those receiving any dose of paliperidone palmitate were significantly less likely to show no improvement in global state $(n=1696,4$ RCTs, RR 0.79 CI $0.74-0.85$, NNTB 7 CI 5-9). People randomized to paliperidone palmitate were less likely to experience a recurrence of psychosis $(n=312,1$ RCT, RR 0.28 CI $0.17-0.48$, NNTB 5 CI 4-6) than those allocated to placebo in a single trial specifically designed to study recurrence. In the other studies where recurrence was recorded only as an adverse event, we found that people who received paliperidone palmitate were also less likely to experience a recurrence of psychotic symptoms $(n=1837,4$ RCTs, RR 0.55 CI $0.44-0.68$, NNTB 10 CI 8-14). Paliperidone palmitate was associated with fewer reports of agitation or aggression $(n=2180,5$ RCTs, RR 0.65 CI 0.46-0.91, NNTB 39 CI 25-150) and of using anxiolytic medications $(n=2170$, 5 RCTs, RR 0.89 CI 0.83-0.96, NNTB 16 CI 11-44). A consistent, significant elevation in serum prolactin (ng/ $\mathrm{mL}$ ) was found for both men and women receiving paliperidone palmitate, but the data was too heterogenous to sum. We found no evidence of sexual dysfunction in these short-term trials. People receiving paliperidone palmitate had a significantly greater increase in weight $(n=2052$, 5 RCTs, WMD 1.34 CI 0.97 to 1.70) in comparison with people who received placebo.

Two studies with 1969 participants compared flexibly-dosed paliperidone palmitate with flexibly dosed risperidone long-acting injection. The mean doses of paliperidone palmitate in these trials were 73.3 and $104.6 \mathrm{mg}$ every 4 weeks compared with risperidone long-acting injection at mean doses, respectively, of 35.3 and $31.7 \mathrm{mg}$ every 2 weeks. We found no differences between paliperidone palmitate and risperidone longacting injection for leaving these studies early for any 
Table 1. Summary of Findings Table

\section{Paliperidone palmitate compared to risperidone long-acting injection for schizophrenia}

Patient or population: people with schizophrenia

Settings: mostly outpatient

Intervention: paliperidone palmitate

Comparison: risperidone long-acting injection

\begin{tabular}{|c|c|c|c|c|c|c|}
\hline \multirow[b]{2}{*}{ Outcomes } & \multicolumn{2}{|c|}{ Illustrative comparative risks* $(95 \% \mathrm{CI})$} & \multirow[b]{2}{*}{$\begin{array}{l}\text { Relative } \\
\text { effect } \\
(95 \% \mathrm{CI})\end{array}$} & \multirow[b]{2}{*}{$\begin{array}{l}\text { No of } \\
\text { Participants } \\
\text { (studies) }\end{array}$} & \multirow[b]{2}{*}{$\begin{array}{l}\text { Quality of } \\
\text { the evidence } \\
\text { (GRADE) }\end{array}$} & \multirow[b]{2}{*}{ Comments } \\
\hline & $\begin{array}{l}\text { Assumed risk } \\
\text { Risperidone long- } \\
\text { acting injection }\end{array}$ & $\begin{array}{l}\text { Corresponding risk } \\
\text { Paliperidone } \\
\text { palmitate }\end{array}$ & & & & \\
\hline $\begin{array}{l}\begin{array}{l}\text { Leaving the study early-any } \\
\text { reason }\end{array} \\
\text { Reported by trial author } \\
\text { Follow-up: } 13-53 \text { weeks }\end{array}$ & $\begin{array}{l}\text { Study population }{ }^{1} \\
333 \text { per } 1000 \\
\text { Moderate }^{1} \\
366 \text { per } 1000\end{array}$ & $\begin{array}{l}373 \text { per } 1000 \\
(333-416) \\
410 \text { per } 1000 \\
(366-457)\end{array}$ & $\begin{array}{l}\text { RR 1.12 } \\
(1-1.25)\end{array}$ & $\begin{array}{l}1969 \\
\text { (2 studies) }\end{array}$ & $\oplus \oplus \oplus \oplus$ high & \\
\hline $\begin{array}{l}\text { Leaving the study early-lack } \\
\text { of efficacy } \\
\text { Reported by trial author } \\
\text { Follow-up: } 13-53 \text { weeks }\end{array}$ & $\begin{array}{l}\text { Study population }{ }^{1} \\
101 \text { per } 1000 \\
\text { Moderate }^{1} \\
111 \text { per } 1000\end{array}$ & $\begin{array}{l}136 \text { per } 1000 \\
(107-172) \\
150 \text { per } 1000 \\
(118-190)\end{array}$ & $\begin{array}{l}\text { RR 1.35 } \\
(1.06-1.71)\end{array}$ & $\begin{array}{l}1969 \\
\text { (2 studies) }\end{array}$ & $\begin{array}{l}\oplus \oplus \oplus \Theta \\
\text { moderate }\end{array}$ & \\
\hline $\begin{array}{l}\text { Death } \\
\text { Reported by trial author } \\
\text { Follow-up: 13-53 weeks }\end{array}$ & $\begin{array}{l}\text { Study population }{ }^{1} \\
1 \text { per } 1000 \\
\text { Moderate }^{1} \\
1 \text { per } 1000\end{array}$ & $\begin{array}{l}4 \text { per } 1000 \\
(1-22) \\
4 \text { per } 1000 \\
(1-22)\end{array}$ & $\begin{array}{l}\text { RR 3.62 } \\
(0.6-21.89)\end{array}$ & $\begin{array}{l}1967 \\
\text { (2 studies) }\end{array}$ & $\oplus \oplus \ominus \ominus$ low $^{3}$ & \\
\hline $\begin{array}{l}\text { No clinically important } \\
\text { change } \\
\text { Number of people whose } \\
\text { PANSS score either } \\
\text { increased or did not } \\
\text { decrease by at least } 30 \% \\
\text { from the beginning to the } \\
\text { end of the trial } \\
\text { Follow-up: } 13-53 \text { weeks }\end{array}$ & $\begin{array}{l}\text { Study population }^{1} \\
492 \text { per } 1000 \\
\text { Moderate }^{1} \\
487 \text { per } 1000\end{array}$ & $\begin{array}{l}507 \text { per } 1000 \\
(457-561) \\
502 \text { per } 1000 \\
(453-555)\end{array}$ & $\begin{array}{l}\text { RR 1.03 } \\
(0.93-1.14)\end{array}$ & $\begin{array}{l}1587 \\
\text { (2 studies) }\end{array}$ & $\oplus \oplus \ominus \ominus$ low 2,4 & \\
\hline $\begin{array}{l}\text { Relapse: recurrence of } \\
\text { psychotic symptoms } \\
\text { Reported by trial } \\
\text { authors as adverse event } \\
\text { Follow-up: } 13-53 \text { weeks }\end{array}$ & $\begin{array}{l}\text { Study population }^{1} \\
118 \text { per } 1000 \\
\text { Moderate }^{1} \\
135 \text { per } 1000\end{array}$ & $\begin{array}{l}145 \text { per } 1000 \\
(115-180) \\
166 \text { per } 1000 \\
(132-207)\end{array}$ & $\begin{array}{l}\text { RR 1.23 } \\
(0.98-1.53)\end{array}$ & $\begin{array}{l}1961 \\
\text { (2 studies) }\end{array}$ & $\begin{array}{l}\oplus \oplus \oplus \Theta \\
\quad \text { moderate }^{5}\end{array}$ & \\
\hline Cost & See comment & See comment & $\begin{array}{l}\text { Not } \\
\text { estimable }\end{array}$ & - & Not reported & \\
\hline Health related quality of life & See comment & See comment & $\begin{array}{l}\text { Not } \\
\text { estimable }\end{array}$ & - & Not reported & \\
\hline
\end{tabular}

Note: CI: Confidence interval; RR: Risk ratio.

GRADE Working Group grades of evidence.

High quality: Further research is very unlikely to change our confidence in the estimate of effect; moderate quality: Further research is likely to have an important impact on our confidence in the estimate of effect and may change the estimate; low quality: Further research is very likely to have an important impact on our confidence in the estimate of effect and is likely to change the estimate; very low quality: We are very uncertain about the estimate.

${ }^{1}$ This is the median risk for studies included in the review.

${ }^{2}$ Data are skewed. (One trial strongly favors risperidone LAI, and another with no significant difference. The latter trial trial is shorter and may not have been long enough to identify this difference.)

${ }^{3}$ Not statistically significant, but given the import of this finding, we wanted to highlight this outcome for further study.

${ }^{4}$ The PANSS is primarily used in research studies rather than in clinical practice, so is an indirect measure of the absence of a clinically important change.

${ }^{5}$ Neither study included recurrence as a specific outcome, but simply recorded recurrence as an adverse event.

*The basis for the assumed risk (e.g. the median control group risk across studies) is provided in footnotes. The corresponding risk (and its $95 \%$ confidence interval) is based on the assumed risk in the comparison group and the relative effect of the intervention (and its $95 \% \mathrm{CI}$ ). 


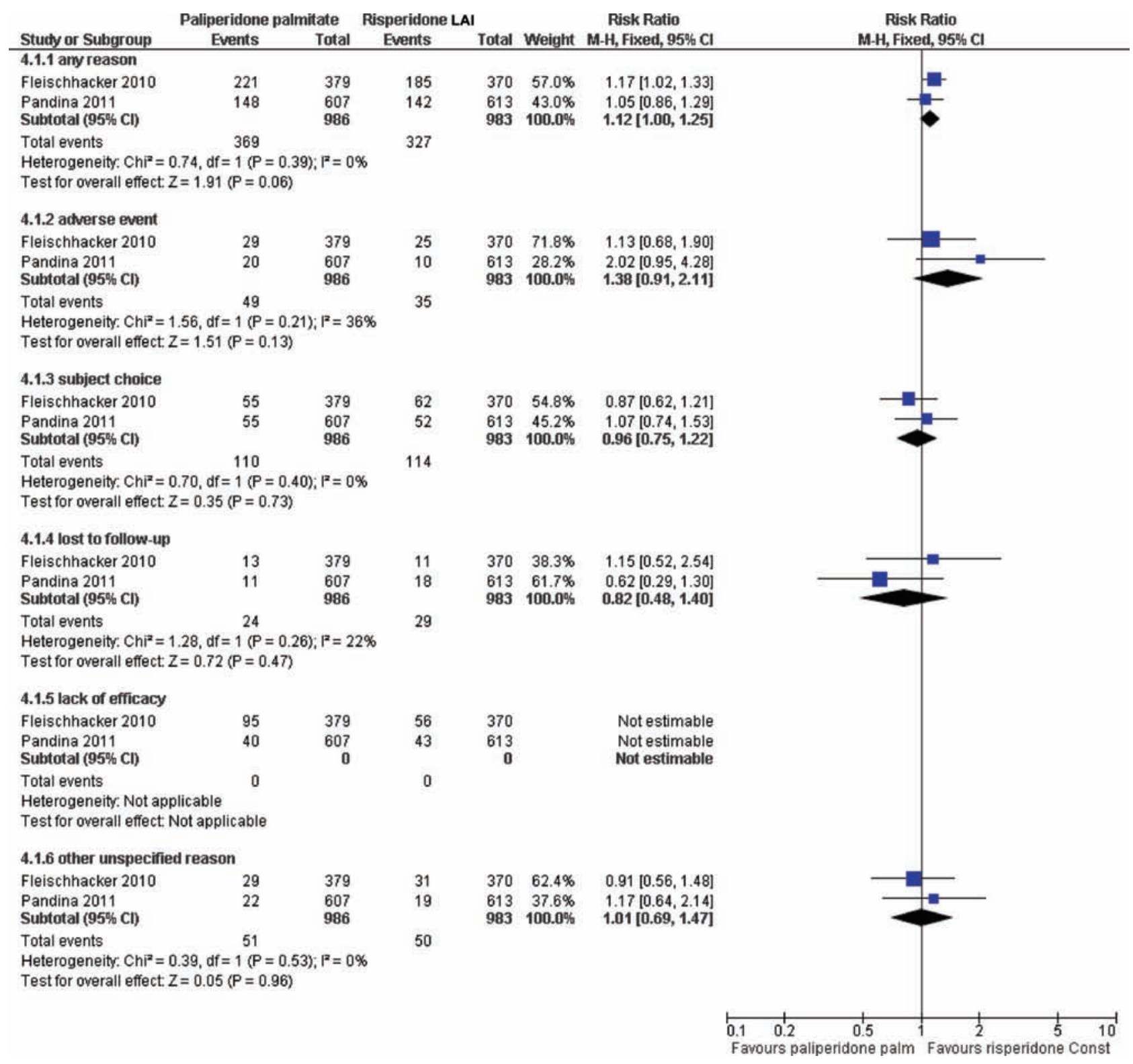

Fig. 1. Leaving the study early for any reason.

reason ( $n=1969,2$ RCTs, RR 1.12 CI 1.00-1.25). Those receiving paliperidone palmitate were statistically no more likely to have a recurrence of psychotic symptoms than those receiving risperidone LAI $(n=1961,2$ RCTs, RR 1.23 CI 0.98-1.53). Although we found no significant difference in the occurrences of deaths in the pooled trials $(n=1967,2$ RCTs, RR 3.62 CI 0.6021.89), we note that a total of six deaths occurred in these two trials, with five deaths among people who received paliperidone palmitate and one death among people who received risperidone long-acting injection. Although death is the most serious of adverse events, the small number of these events in these trials makes it unclear if this finding is meaningful. We found that subjects randomized to paliperidone palmitate were significantly less likely to use anticholinergic medications in these trials ( $n=1587,2$ RCTs, RR 0.67 CI 0.55-0.82, NNTB 13 CI 10-24).

We found no data regarding paliperidone palmitate relating to services use, quality of life, patient satisfaction, or cost.

\section{Authors' Conclusions}

In short-term studies, paliperidone palmitate is an antipsychotic drug that is more efficacious than placebo. We found its adverse effects to be similar to those of its related compounds, paliperidone and risperidone, with extrapyramidal movement disorders, weight gain, and tachycardia all more common with paliperidone 
palmitate than placebo. Although no difference was found in the incidence of reported adverse sexual outcomes, paliperidone palmitate is associated with substantial increases in serum prolactin. When flexibly dosed with mean doses of approximately $70-110 \mathrm{mg}$ every 4 weeks, paliperidone palmitate appears comparable in efficacy and tolerability to risperidone long-acting injection flexibly dosed with mean doses of approximately $35 \mathrm{mg}$ every 2 weeks.

\section{Reference}

1. Nussbaum AM, Stroup TS. Paliperidone palmitate for schizophrenia. Cochrane Database Syst Rev. 2012s. Art. No.: CD008296. doi:10.1002/14651858.CD008296.pub2. 